\title{
Plant phenotype affects oviposition behaviour of pine processionary moth and egg survival at the southern edge of its range
}

\author{
Sara Hezil ${ }^{(1)}$, \\ Gahdab Chakali ${ }^{(1)}$, \\ Andrea Battisti ${ }^{(2)}$
}

\begin{abstract}
Morphological traits of Aleppo pine (Pinus halepensis) needles in native and planted stands at the southern edge of its range influence oviposition behaviour of the pine processionary moth (Thaumetopoea pityocampa). Extreme environmental conditions result in a reduction in needle size of the host plant which corresponds to a lower rate of fecundity in the moth. Our results showed that egg batches were laid closer to the needle buds, especially on native trees with short needles, and this resulted in increased egg mortality. Number of eggs laid by the female moths did not vary between native and planted stands, nor did the number of parasitized eggs of the two common $\mathrm{Hy}$ menopteran parasitoids, Baryscapus servadeii and Ooencyrtus pityocampae. The observed differences in egg mortality are likely due to abiotic factors associated with the position of the egg batch on the needles. Thaumetopoea pityocampa eggs require a thermal niche for optimal development, and further measurements are required to determine the thermal threshold of these eggs. Understanding the role of climate in T. pityocampa populations will be an important factor for the survival of the Aleppo pine forests and protecting it from desertification.
\end{abstract}

\section{Keywords: Algeria, Egg Parasitoid, Pinus halepensis, Plantation, Thaumeto- poea pityocampa}

\section{Introduction \\ Aleppo pine forests (Pinus halepensis Mill.) are widely distributed in the Mediter- ranean region (Critchfield \& Little 1966) and are highly susceptible to periodic at- tacks by the pine processionary moth Thaumetopoea pityocampa (Denis \& Schif- fermüller 1775, Lepidoptera: Notodonti- dae). This species is considered the most important defoliator of both native and ar- tificial stands of pines and other conifers such as cedars (Martin 2005); causing sig nificant economic loss from attacked stands. Larvae of $T$. pityocampa also have urticating hairs which cause serious allergic}

(1) École Nationale Supérieure d'Agronomie, El-Harrach, 16200 Alger (Algérie); (2) Department DAFNAE-Entomology, University of Padova, Agripolis, I-35020 Legnaro, PD (Italy)

\section{@ Sara Hezil (sara.hezil.ensa@gmail.com)}

Received: Nov 03, 2017 - Accepted: Jul 03, 2018

Citation: Hezil S, Chakali G, Battisti A (2018). Plant phenotype affects oviposition behaviour of pine processionary moth and egg survival at the southern edge of its range. iForest 11: 572-576. - doi: 10.3832/ifor2675-011 [online 2018-09-01]

Communicated by: Massimo Faccoli reactions to humans and animals (Battisti et al. 2015). Despite a number of studies on the biology and ecology of this species, its oviposition behaviour relating to the morphology of the host plant is poorly understood.

An earlier study determined that T. pityocampa selects pines with rapid growth, long needles and low content of secondary metabolites such as limonene, to ensure the offspring are provided with the best available resources (Pérez-Contreras et al. 2008). In this perspective, Aleppo pine offers better oviposition conditions for the processionary moth compared to the maritime pine Pinus pinaster Ait. (Pérez-Contreras et al. 2013). Thompson \& Pellmyr (1991) stated that the host trees selected by females should offer the highest nutritional content for the offspring, and this factor was important for the expansion of processionary moth populations in the Alps (Stastny et al. 2006). Furthermore, olfactory and visual cues played an important role in the preference for oviposition on edge trees, as observed in pine plantations by Paiva et al. (2011) and Dulaurent et al. (2012). Additionally, Zhang et al. (2003) studied the role of terpenes in host selection by female moths and determined that female antennae responded strongly to four monoterpenes, i.e., myrcene, b-phellandrene, trans-b-ocimene, and terpinolene. Another study stated that physical and chemical traits of the host plant can influence the selection of oviposition sites (Renwick \& Chew 1994). Therefore, these findings may be important factors for the population dynamics of T. pityocampa (Jactel et al. 2015)

Oviposition choice by female T. pityocampa moths may indirectly affect the activity of egg parasitoids. Two principal egg parasitoids are known for T. pityocampa, the specialist Baryscapus servadeii (Domenichini 1965, Hymenoptera: Eulophidae) and the generalist Ooencyrtus pityocampae (Mercet 1921, Hymenoptera: Encyrtidae Battisti 1989). The generalist O. pityocampae has a more flexible host selection, it can adapt its development to hosts of different origins and size (Ruschioni et al. 2015), while the specialist B. servadeii is more dependent on the quality of the host plant (Battisti 1989). Thus, the differences in the quality of host plant available for oviposition may influence the performance of parasitoids (Medina \& Barbosa 2008).

The hatching of pine processionary moth larvae may be affected by temperature and exposure to solar radiation (Milani 1990). The temperature of egg batches with and without scales differed strongly in relation to the intensity of solar radiation in a prealpine valley located in Friuli, North-East of Italy, with higher temperature in egg batches with scales and exposed to the sun. In addition, the temperature of egg batches was remarkably higher than the temperature of the pine needle where the eggs were oviposited (Milani 1990).

The aim of this study was to explore the effect of host plant needle traits on the oviposition of female pine processionary 
Tab. 1 - Location coordinates of the study sites.

\begin{tabular}{llccc}
\hline \multirow{2}{*}{ Stands } & \multirow{2}{*}{ Sites } & $\begin{array}{c}\text { Elevation } \\
(\mathrm{m} \text { a.s.I. })\end{array}$ & \multicolumn{2}{c}{ Coordinates } \\
\cline { 4 - 5 } & & 1255 & $3^{\circ} 23^{\prime} 18.79^{\prime \prime}$ & $34^{\circ} 36^{\prime} 39.22^{\prime \prime}$ \\
\hline Planted & S1 & 1344 & $3^{\circ} 01^{\prime} 24.85^{\prime \prime}$ & $34^{\circ} 31^{\prime} 12.47^{\prime \prime}$ \\
& S2 & 1257 & $3^{\circ} 15^{\prime} 35.86^{\prime \prime}$ & $34^{\circ} 51^{\prime} 00.77^{\prime \prime}$ \\
& S3 & 1333 & $3^{\circ} 08^{\prime} 11.25^{\prime \prime}$ & $34^{\circ} 38^{\prime} 07.19^{\prime \prime}$ \\
Native & S4 & 1339 & $2^{\circ} 46^{\prime} 40.31^{\prime \prime}$ & $34^{\circ} 32^{\prime} 59.56^{\prime \prime}$ \\
& S5 & 1291 & $3^{\circ} 23^{\prime} 30.96^{\prime \prime}$ & $34^{\circ} 55^{\prime} 56.85^{\prime \prime}$ \\
\hline
\end{tabular}

moths in native and artificial stands of Aleppo pine in Algeria. As pine needles under these extreme conditions are generally shorter than normal, we wanted to test if the needle traits affect the oviposition behaviour of the female moths; this was based on the hypothesis developed by Demolin (1969) about the optimal thickness for oviposition. We also tested if oviposition choice had consequences on hatching performance, based on the study by Milani (1990) about the role of temperature, solar radiation, and parasitism by the two major egg parasitoids.

\section{Materials and methods}

\section{Study site}

This study was conducted between 2012 and 2014 in a semi-arid area located in the Saharian Atlas Mountains (Algeria), around the town of Djelfa, $300 \mathrm{~km}$ south of Algiers, at an elevation of about 1250-1344 m a.s.l. (Tab. 1). This area is characterized by an annual average temperature of $8.4{ }^{\circ} \mathrm{C}$ and annual average precipitation of 324

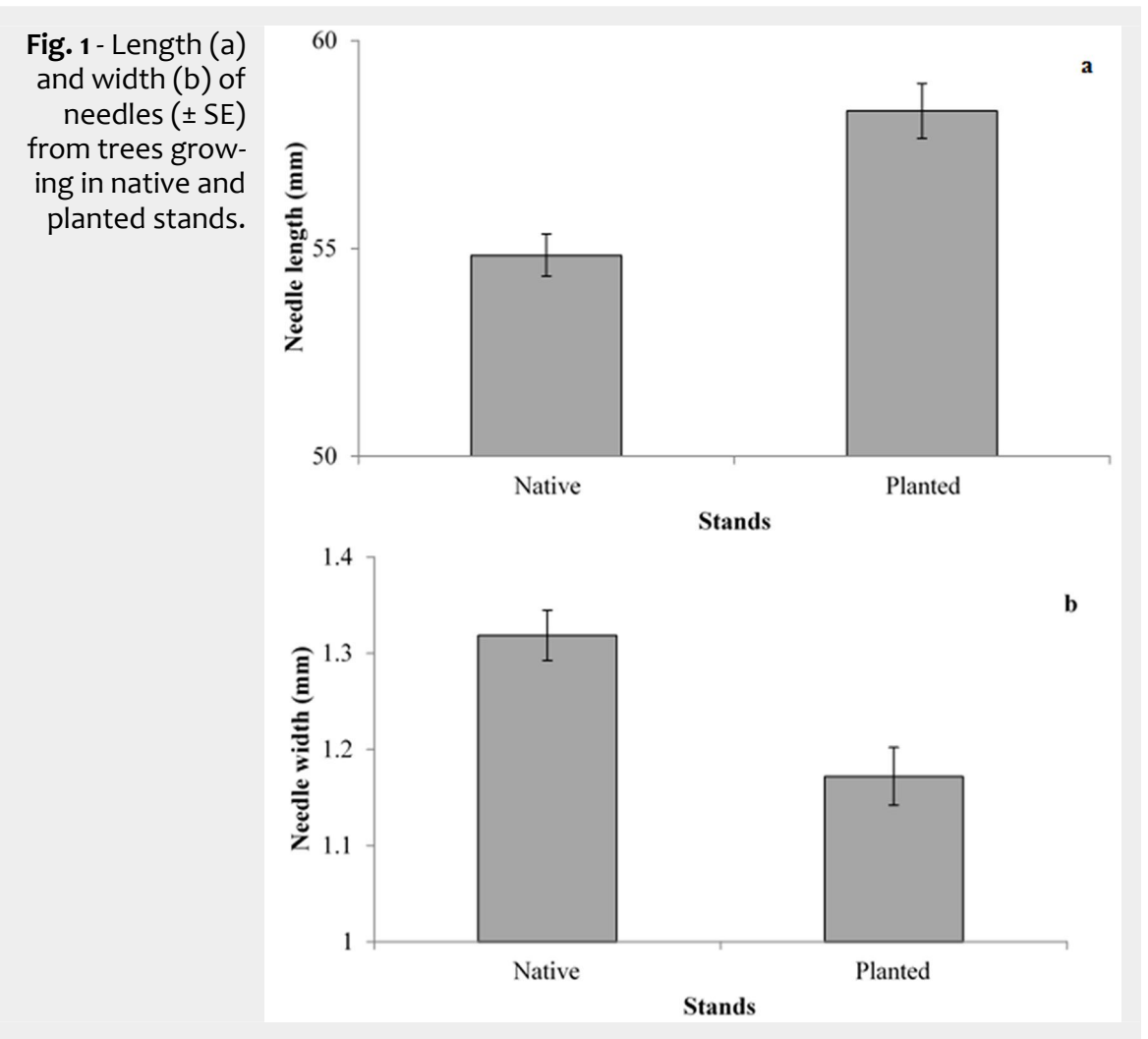

\section{Egg batches collection}

Egg batches of $T$. pityocampa were collected from trees growing in three native and three planted stands (Tab. 1) between the end of August and beginning of September each year for 2 years. Eggs started hatching in the laboratory from around mid-September. In total, 964 needle pairs carrying egg batches were randomly collected at an accessible height from $P$. halepensis distributed throughout the stands, with a maximum of three egg batches collected per tree. In 2012, a total of 242 egg batches were collected ( 32 from S1, 106 from S2, 34 from S4, and 70 from S5). In 2014, 842 egg batches were collected (217 from S1, 176 from S2, 60 from S3, 160 from S4, 169 from S5, and 62 from S6). At the laboratory, egg batches on the needle pairs were removed and put in individual test tubes of $10 \mathrm{~cm}$ length and $1 \mathrm{~cm}$ diameter. Laboratory temperature was set at $26 \pm 2{ }^{\circ} \mathrm{C}$, and the emergence of egg parasitoids from these egg batches were closely monitored. Ninety needle pairs per site without egg batches from the same trees were collected as a control for analysing the morphology of the needles. campa in the last decades (Zamoum et al. 2015). The population is genetically related to the pityocampa clade and shares mitochondrial DNA haplotypes with the populations of south Morocco, whereas the nuclear DNA is closer to the one of ENA clade of the eastern Maghreb (El Mokhefi et al. 2016). This T. pityocampa population is located at the most southern edge of its species range and has the lowest average fecundity within this species (Zamoum et al. 2015).

\section{Analysis of needles}

Position of the egg batch on the needle pair may vary from basal to central or apical. To assess the needle traits in each section, the needles were divided into three parts. Basal part was characterised as the leaf bud to the first egg of the egg batch, medium part was the area covered by the whole egg batch, and apical part was the area above the egg batch. Each part was measured for length, diameter, and dry weight. Length and diameter of randomly chosen control needles were also measured.

\section{Analysis of egg batches}

At the end of the parasitoids emergence (spring from the following year of collection), all egg batches were analysed to determine the percentage of hatched and unhatched T. pityocampa eggs, and rate of egg parasitism. Eggs were assigned to the following categories: successfully hatched (presence of a large hole and empty shell), unhatched eggs (intact egg shell), hatched failure (egg shell open as for successfully hatched but with a dead larva inside), successful parasitism by 0 . pityocampae (egg shell with a small hole not in the centre and with an irregular edge), and successful parasitism by $B$. servadeii (egg shell with a small hole in the centre and with a regular edge).

\section{Statistical analysis}

Analyses were done using a linear mixed model to account for the effects of stand type and distance of the egg batch from the needle bud, on the dependent variables (log transformed number of unhatched eggs, and percentage of eggs parasitized by $O$. pityocampae and by $B$. ser- 
vadeii). Interaction among factors was tested to detect if egg mortality was related to distance of the egg batch from the needle bud in native and planted stands. Trees within sites were used as a random effect. All statistical tests were made using the package "nlme" (Pinheiro et al. 2017) in R ver. 3.2.0.

\section{Results}

Two years of sampling did not result in significant differences between the types of stand for any of the variables considered, and for this reason the data were pooled. Needle pairs without egg batches were slightly longer and heavier in planted than in native stands (Fig. 1a), although differences were marginally significant $(p=$ 0.08). Thickness of the needles, measured as needle width, differed significantly between the stands $\left(F_{1,172}=13.7, p<0.01-\right.$ Fig. $1 b)$. Distance between the needle bud and the beginning of the egg batch was not significantly different between native and planted stands, even though the egg batches tend to be closer to needle buds in native stands $\left(F_{1,165}=1.14, p=0.397\right.$ - Fig. 2). As needles from planted stands were slightly longer and thinner than those of the native stands, the section of the needles carrying eggs was longer in planted than in native stands $\left(F_{1,499}=33.38, p<0.01\right.$ - Fig. 2), while the average number of eggs per egg batch was similar between planted and native stands (Tab. 2).

Overall egg mortality (including all factors shown in Tab. 2) decreased significantly with the increase in distance of the egg batch from the needle bud, for both native and planted stands $\left(F_{1,165}=251.64, p<0.01\right)$, indicating that egg mortality was higher when eggs were laid closer to the needle bud. Interestingly, slope of the regression was significantly higher in native than in planted stands $\left(F_{1,165}=13.25, p<0.01-\right.$ Fig. $3)$, suggesting a stronger role of mortality factors in native stands.

Number of eggs successfully parasitized by $O$. pityocampae (overall $1.9 \%$ ) and by $B$.

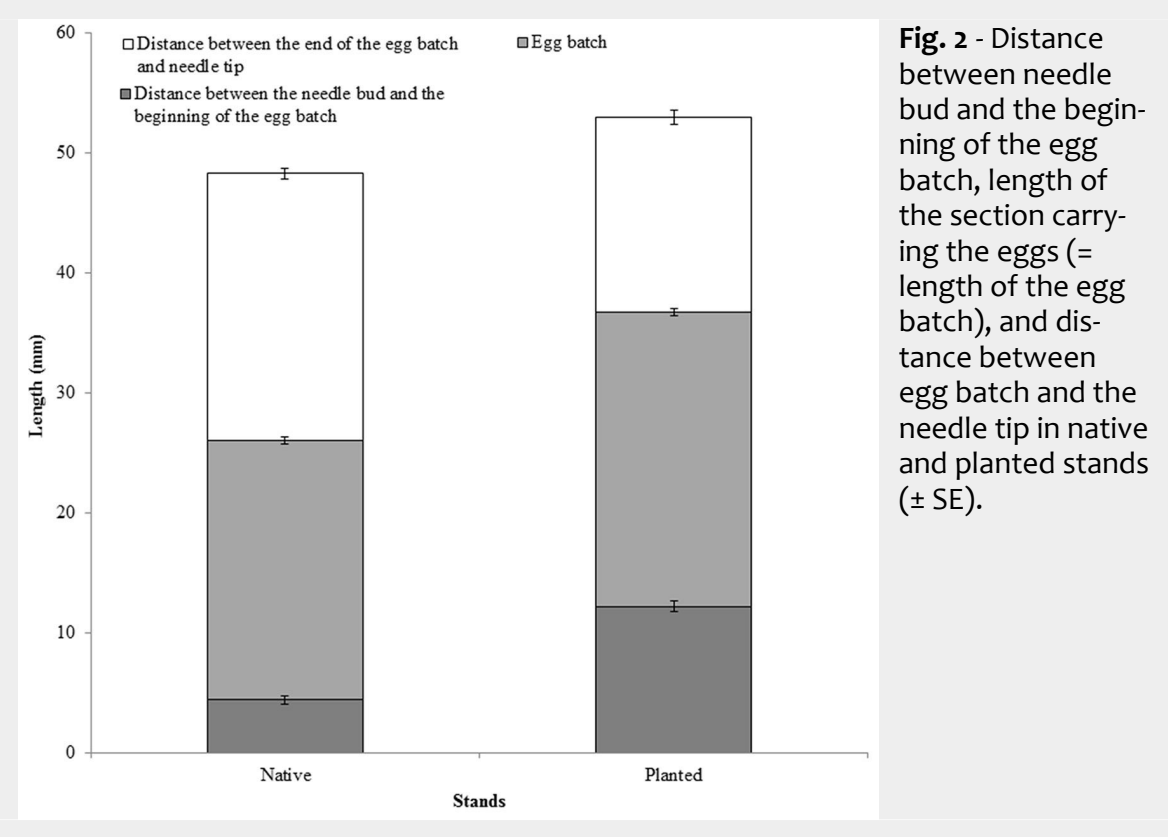

Tab. $\mathbf{2}$ - Characteristics of the egg batches laid on trees of native and planted stands (average $\pm \mathrm{SE}$ ).

\begin{tabular}{llc}
\hline \multirow{2}{*}{ Parameters } & \multicolumn{2}{c}{ Stands } \\
\cline { 2 - 3 } & Native & Planted \\
\hline Number of egg batches & 104 & 138 \\
Number of eggs & $134.6 \pm 3.5$ & $135.3 \pm 2.8$ \\
Successfully hatched eggs & $87.0 \pm 5.3$ & $107.2 \pm 2.7$ \\
Hatched eggs with dead larvae & $15.6 \pm 2.2$ & $3.5 \pm 0.5$ \\
Unhatched eggs & $41.7 \pm 3.7$ & $13.1 \pm 0.6$ \\
Eggs parasitized by O. pityocampae & $3.3 \pm 0.4$ & $2.1 \pm 0.07$ \\
Eggs parasitized by B. servadeii & $7.1 \pm 0.6$ & $7.0 \pm 0.5$ \\
\% of O. pityocampae & 2.4 & 1.5 \\
\% of B. servadeii & 5.3 & 5.2 \\
\hline
\end{tabular}

servadeii (overall $5.2 \%$ ) did not differ significantly between the two stands, as well as the distance of egg batch from the needle bud (Tab. 2).

\section{Discussion}

At the very southern edge of the range of This observation is not surprising consider-
Fig. 3 - Relationships between the number of unhatched eggs and distance between needle bud and the beginning of the egg batch in native and planted stands. Dots represent the individual egg batches.

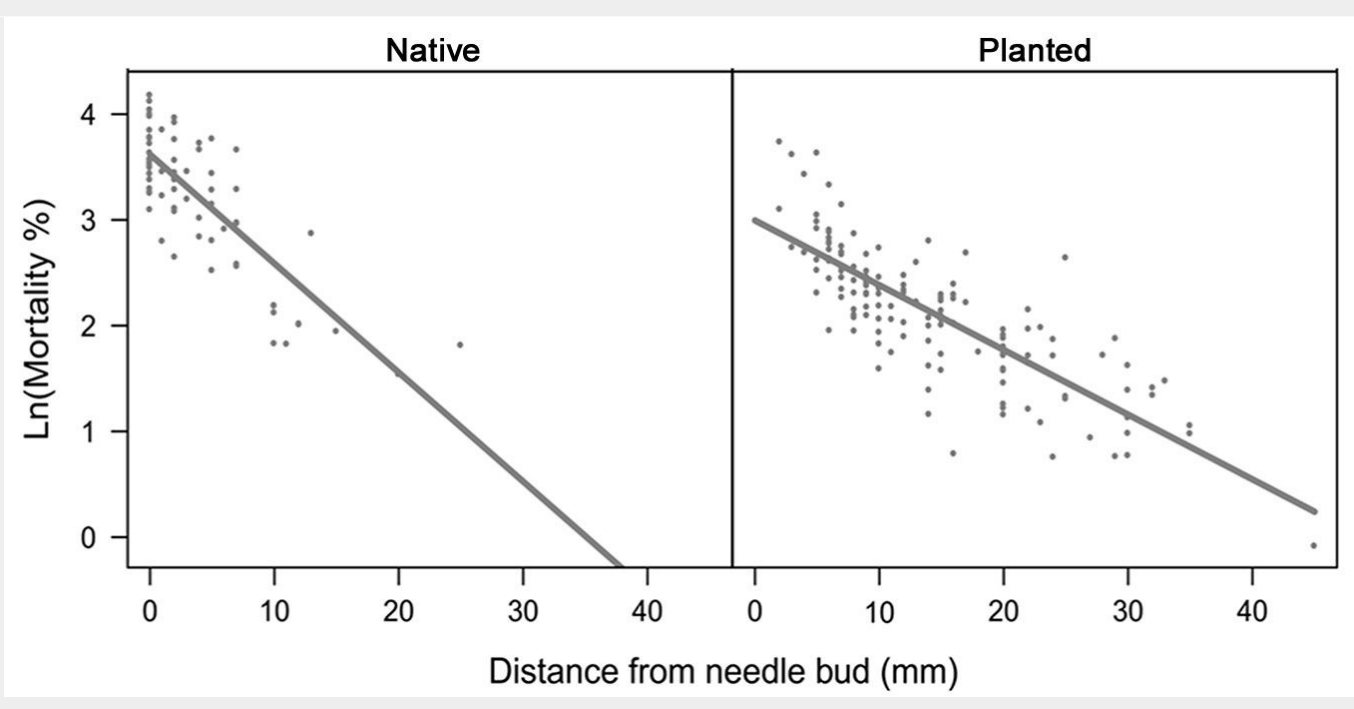


ing the low amount of precipitation (less than $400 \mathrm{~mm}$, semi-arid zone) and high temperatures during summer. Interestingly, we have found that there were morphological differences in pine needles between native and planted stands which affected egg mortality rates and oviposition patterns of the pine processionary moth.

Egg mortality of T. pityocampa was lower when eggs were laid on pine needles far from the needle bud in both native and planted stands; effects were more pronounced in the latter, likely because the needles were slightly longer and thinner than in native stands. As number of eggs laid by female moths did not vary between the types of stands, the observed differences are likely to be explained by the needle size. According to Demolin (1969), the ideal diameter of the needle pair for suitable oviposition varies from 1.6 to $2 \mathrm{~mm}$; while in our case, the diameter of the needle pair did not exceed $1.4 \mathrm{~mm}$. Female fecundity, however, is proportionally lower at the southern edge of the range (130-140 eggs per female - this study and Zamoum et al. 2015) compared to the core range (200-240 eggs per female - Demolin 1969, Pimentel et al. 2010). As female moths respond to small variations in needle diameter and inspect pine needles from the base (Demolin 1969), it is likely that they found optimal conditions for ovipositing at a distance from the base on longer needles. Our needles were thinner but the number of eggs per female were similar. Therefore, T. pityocampa eggs were laid over a longer distance compared to the general oviposition behaviour of this species. Based on the same principle, Pimentel et al. (2010) also found that needle morphology affects the length of egg batches.

Position of the eggs on needles had some effects on the performance of pine processionary moth. Mortality was generally higher in egg batches laid closer to the base of the needles, irrespective of the type of stand. Stronger effects of mortality observed in native stands is possibly due to its shorter and thicker needles, which lead to the egg batch being more compact and closer to the needle bud. There were no significant effects of parasitism on mortality rates of T. pityocampa in both stands. A likely explanation for this observed mortality is the abiotic conditions that may have impaired embryonic development and egg hatching. Milani (1990) observed that the scales laid by the female moth to cover the eggs may help to capture solar radiation and significantly increase the temperature of the eggs, compared to egg batches in the shade or egg batches without scale cover. Based on these observations, position of the eggs on the needles could be a factor affecting the amount of solar radiation it receives and thus result in different temperatures. Additionally, shape of the egg batch would also influence the way solar radiation affects the temperature of eggs. Therefore, both position and shape of the egg batch would influence the cooling effect associated with ventilation of the pine shoot. Temperature is known to affect embryonic development in the pine processionary moth, and differences are already detected among populations (Santos et al. 2011). Consequently, oviposition pattern may have affected the egg survival in this population at the southern edge of the range under rather extreme conditions. Measuring temperatures experienced by the eggs in native and planted stands are required to establish the causes of difference in mortality rates.

In conclusion, we suggest that egg mortality is associated with distance of the egg batch from the needle bud. Egg mortality from egg parasitoids 0 . pityocampae and B. servadeii did not vary with distance of the egg batches from the needle bud; therefore, other mortality factors have to be invoked. Among these, abiotic factors associated with thermoregulation should be considered, because of the extreme conditions these eggs are exposed to. Specific measures of egg thermal niche should be taken in the field and laboratory to understand the observed pattern and to use the data for predictive models on egg mortality. This will be important for the survival of pine forests in this region, and it is essential for combating desertification and providing local communities with essential services.

\section{Acknowledgements}

The authors thank Lorenzo Marini for helping with the statistical analysis and University of Padova, DAFNAE for hosting the first author scientific visit. Special thanks to Ahmad A.D. Alshashani for his advice and suggestions, to Mustafa Avci for his comments, to anonymous reviewers who helped to improve the manuscript, and to Mizuki Uemura for language check and editing.

\section{References}

Battisti A (1989). Field studies on the behaviour of two egg parasitoids of the pine processionary moth Thaumetopoea pityocampa. Entomophaga 34: 29-38. - doi: 10.1007/BF02372584 Battisti A, Avci M, Avtzis DN, Ben Jamaa ML, Berardi L, Berretima WA, Branco $M$, Chakali $G$, El Alaoui El Fels MA, Frérot B, Hodar JH, lonescuMalancus I, Ipekdal K, Larsson S, Manole T, Mendel Z, Meurisse N, Mirchev P, Nemer N, Paiva MR, Pino J, Protasov A, Rahim N, Rousselet J, Santos H, Sauvard D, Schopf A, Simonato M, Yart A, Zamoum M (2015). Natural history of the processionary moths (Thaumetopoea spp.): new insights in relation to climate change. in: "Processionary Moths and Climate Change. An Update" (Roques A ed). Springer, Dordrecht, Netherlands and Quae, Versailles, France, pp. 15-80.

Critchfield W, Little E (1966). Geographic distribution of the pines of the world. Miscellaneous Publication no. 991, USDA Forest Service, Washington, DC, USA, pp. 96. - doi: 10.5962/bhl.tit le. 66393
Demolin G (1969). Comportement des adultes de Thaumetopoea pityocampa Schiff. Dispersion spatiale, importance écologique [Behavior of adults of Thaumetopoea pityocampa Schiff. Spatial dispersion, ecological importance]. Annales des Sciences Forestières 26: 81-102. [in French] - doi: 10.1051/forest/19690104

Dulaurent AM, Porté AJ, Van Halder I, Vétillard F, Menassieu P, Jactel H (2012). Hide and seek in forests: colonization by the pine processionary moth is impeded by the presence of non host trees. Agricultural and Forest Entomology 14: 19-27. - doi: 10.1111/j.1461-9563.2011.00549.x

El Mokhefi M, Kerdelhué C, Burban C, Battisti A, Chakali G, Simonato M (2016). Genetic differentiation of the pine processionary moth at the southern edge of its range: contrasting patterns between mitochondrial and nuclear markers. Ecology and Evolution 6: 4274-4288. - doi: 10.1002/ece3.2194

Jactel H, Barbaro L, Battisti A, Bosc A, Branco M, Brockerhoff E, Castagneyrol B, Dulaurent AM, Hódar JA, Jacquet JS, Mateus E, Paiva MR, Roques A, Samalens JC, Santos H, Schlyter F (2015). Insect-tree interactions in Thaumetopoea pityocampa. In: "Processionary Moths and Climate Change. An Update" (Roques A ed). Springer, Dordrecht, Netherlands and Quae, Versailles, France, pp. 265-310. - doi: 10.1007/97 8-94-017-9340-7

Martin JC (2005). La processionnaire du pin, Thaumatopoea pityocampa (Denis et Schiffermüller). Biologie et protection des forêts. Synthèse des recherches bibliographiques et des connaissances [The pine processionary moth, Thaumatopoea pityocampa (Denis \& Schiffermüller). Biology and forest protection. Synthesis of bibliographic researches and knowledge]. INRA, Avignon, France, pp. 62. [in French] Medina RF, Barbosa P (2008). The role of host plant species in the phenotypic differentiation of sympatric populations of Aleiodes nolophanae and Cotesia marginiventris. Entomologia Experimentalis et Applicata 128: 14-26. - doi: 10.1111 /j.1570-7458.2008.00736.x

Milani N (1990). The temperature of the egg masses of Thaumetopoea pityocampa (Dens. \& Schiff.) (Lepidoptera, Thaumetopoeidae). Redia 73: 149-161.

Mirchev P, Tsankov G, Douma-Petridou E, Avtzis $\mathrm{N}$ (2010). Comparative analysis of participation of egg parasitoids of pine processionary moth, Thaumetopoea pityocampa (Den. \& Schiff.) (Lep., Thaumetopoeidae) in northern and southern mainland Greece. Silva Balcanica 11: 73-97. [online] URL: http://www.researchgate. net/publication/259644790

Paiva MR, Mateus E, Santos MH, Branco M (2011). Pine processionary moth females use semiochemicals for host selection. IOBC/WPRS Bulletin 72: 159-164.

Pérez-Contreras T, Soler JJ, Soler M (2008). Needle asymmetry, pine vigour and pine selection by the pine processionary moth Thaumetopoea pityocampa. Acta Oecologica 33: 213-221. - doi: 10.1016/j.actao.2007.11.004

Pérez-Contreras T, Soler JJ, Soler M (2013). Host selection by the pine processionary moth enhances larval performance: An experiment. Acta Oecologica 55: 15-22. - doi: 10.1016/j.actao. 2013.10.006 
Pimentel C, Ferreira C, Nilsson JA (2010). Latitudinal gradients and the shaping of life-history traits in a gregarious caterpillar. Biological Journal of the Linnaean Society 100: 224-236. - doi: 10.1111/j.1095-8312.2010.01413.x

Pinheiro J, Bates D, DebRoy S, Sarkar D, R Core Team (2017). nlme: linear and nonlinear mixed effects models. R package version 3: 1-131. [online] URL: http://CRAN.R-project.org/package= nlme

Renwick JAA, Chew FS (1994). Oviposition behavior in Lepidoptera. Annual Review of Entomology 39: 377-400. - doi: 10.1146/annurev.en. 39.010194.002113

Ruschioni S, Riolo P, Isidoro N, Romani R, Petrucco-Toffolo E, Zovi D, Battisti A (2015). Contrasting patterns of host adaptation in two egg parasitoids of the pine processionary moth
(Lepidoptera: Thaumetopoeidae). Environmental Entomology 44: 480-487. - doi: 10.1093/ee/ nvv059

Sahraoui B (1995). Bilan critique du barrage vert en Algérie [Critical assessment of green dam in Algeria]. Secheresse 6: 247-255. [in French]

Santos H, Paiva MR, Tavares C, Kerdelhué C, Branco M (2011). Temperature niche shift observed in a Lepidoptera population under allochronic divergence. Journal of Evolutionary Biology 24: 1897-1905. - doi: 10.1111/j.1420-910 1.2011.02318.x

Stastny M, Battisti A, Petrucoo ET, Schlyter F, Larsson S (2006). Host-plant use in the range expansion of the pine processionary moth, Thaumetopoea pityocampa. Ecological Entomology 31: 481-490. - doi: 10.1111/j.1365-2311.20 06.00807.x
Thompson JN, Pellmyr O (1991). Evolution of oviposition behavior and host preference in Lepidoptera. Annual Review of Entomology 36: 5-89. - doi: 10.1146/annurev.en.36.010191.0004 33

Zamoum M, Martin JC, Bensidi A (2015). Fecundity of the pine processionary moth Thaumetopoea pityocampa (Lepidoptera: Notodontidae) at the southern edge of its distribution range. Biologia 70: 386-392. - doi: 10.1515/biol og-2015-0036

Zhang QH, Schlyter F, Battisti A, Birgersson G, Anderson $P$ (2003). Electrophysiological responses of Thaumetopoea pityocampa females to host volatiles: implications for host selection of active and inactive terpenes. Journal of Pest Science 76: 103-107. - doi: 10.1046/j.1439-0280. 2003.03014.x 